\title{
トリプレット画像を用いたカメラキャリブレーション手法に関する研究
}

\section{Camera Calibration for Digital Camera using Triplet Images}

\author{
柳＼cjkstart秀治*・近津 博文** \\ Hideharu YANAGI and Hirofumi CHIKATSU
}

\begin{abstract}
According to appearance of low cost and high resolution consumer grade digital cameras with various functions, convenient 3D measurement using the digital cameras are enormously expected in various fields. However, there are still problems for efficient digital photogrammetry using the cameras. These problems include 3D measurement for ground control point, previous interior orientation procedures and restriction for taking images. These restrictions should be removed for ideal convenient photogrammetry using the digital cameras.

In order to resolve the above problems, efficient camera calibration method which does not need ground control points nor previous interior orientation procedures are proposed in this paper.
\end{abstract}

\section{1.はじめに}

民生用デジタルカメラの低価格化および高解像度化 が進み, 高解像度撮像素子を搭載した多種, 多様な民 生用デジタルカメラが発売され，手軽に高解像度画像 を手に入れることが可能となった。このため, これま でに民生用デジタルカメラの実用化に関する多数の研 究が報告されている(例えば，Habib and Morgan, 2003 ; Fraser and Hanley, 2004 ; Laebe and Foerstner, 2004)。

しかし，民生用デジタルカメラを用いて写真測量を 行なう場合，一般的には地上基準点を用いてカメラ キャリブレーションを行なう必要があり，地上基準点 設置に伴う測量は簡便な写真測量のボトルネックと なっている。いっぽう，多数の撮影点で取得された多 視点画像に対してフリーネットワーク理論に基づく

* 東京電機大学理工学部

School of Science and Engineering, Tokyo Denki University

**東京電機大学理工学部理工学科 建築・都市環境学系

Division of Architectural, Civil and Environmental

Engineering, Tokyo Denki University

「写真測量とリモートセンシング」VOL. 50，NO. 3， 2011
キャリブレーション手法（Fraser，1996）は地上基準 点を利用しない方法であるが，各撮影点で多数の画像 を撮影する必要があり，簡便的写真測量の実現のため には少ない枚数の写真で，かつ地上基準点測量を必要 としないカメラキャリブレーション法が必要であると 判断される。

このような背景から, 地上基準点を必要としない写 真測量用ソフトウェアが現在多く発売されているが, これらソフトウェアの多くは標定用シートや三次元座 標が既知なテストターゲットを用いてカメラの内部標 定要素を予奴得しておく必要がある。すなわち, 予 め求めておいた内部標定要素をその後の計測において 繰り返し使用することになるが, 我々はこのような場 合にはカメラにもよるが計測精度が 4 倍程度低下する という知見を得ている（高橋・近津，2010）。

したがって，民生用デジタルカメラによる写真測量 の実現には, カメラキャリブレーションの簡略化と計 測精度の維持という，相反する問題に直面することに なるが, 本研究ではこれらの課題に対してトリプレッ 卜画像を利用した簡便的カメラキャリブレーションソ フト “3DiVision”を提案してきたが精度の改善が課題 であった(近津ほか，2003；江島ほか，2006)。そこで, 本研究では中央画像上でのエピポーララインの交点に 対する条件式を制約条件としたキャリブレーション手 
法を提案し，民生用デジタルカメラ14機種を用いて提 案手法の妥当性を検討する。

\section{2.トリプレット画像によるカメラキャリ ブレーション}

本研究におけるカメラキャリブレーションとは 3 箇 所（左，中央，右）に求いて撮影された卜リプレット 画像に対して計測空間中の 2 点間の距離と共線条件式 (式(1)）とを用いて，それぞれのカメラの外部標定要素 および 3 つのカメラに共通な内部標定要素を同時に取 得しようとするものである。なお，本研究ではカメラ キャリブレーションの際にトリプレット画像上に共通 な特徵点を擬似基準点と定めて使用するが，これらの 擬似基準点は画像上で確認できれば良いもので，その 三次元座標は既知である必要はない。また，本手法で は擬似基準点の 1 点 $\left(\mathrm{P}_{0}\right)$ を原点と定め, $\mathrm{X}$ 軸方向を規 定する点を $\mathrm{P}_{1}$ とし, 計測空間中の 2 点間の距離は原 点 $\mathrm{P}_{0}$ と $\mathrm{P}_{1}$ との距離とする。図 1 は本研究における撮 影方法の概念を示したものであり, 以下に詳細なキャ リブレーション手順を示す。

$x=-f \frac{m_{11}\left(X-X_{0}\right)+m_{12}\left(Y-Y_{0}\right)+m_{13}\left(Z-Z_{0}\right)}{m_{31}\left(X-X_{0}\right)+m_{32}\left(Y-Y_{0}\right)+m_{33}\left(Z-Z_{0}\right)}$

$\left.y=-f \frac{m_{21}\left(X-X_{0}\right)+m_{22}\left(Y-Y_{0}\right)+m_{23}\left(Z-Z_{0}\right)}{m_{31}\left(X-X_{0}\right)+m_{32}\left(Y-Y_{0}\right)+m_{33}\left(Z-Z_{0}\right)}\right\}$

ここに, $(X, Y, Z)$ : 擬似基準点の三次元座標, $\left(X_{0}, Y_{0}\right.$, $\left.Z_{0}\right)$ : 撮影点の三次元座標, $(x, y)$ : 擬似基準点の画像 座標, $m_{i j}:$ 回転行列の要素
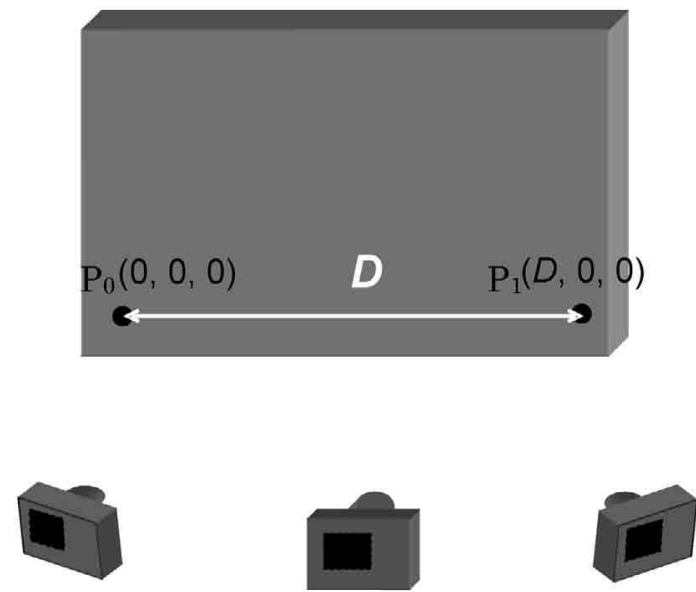

図 1 撮影方法

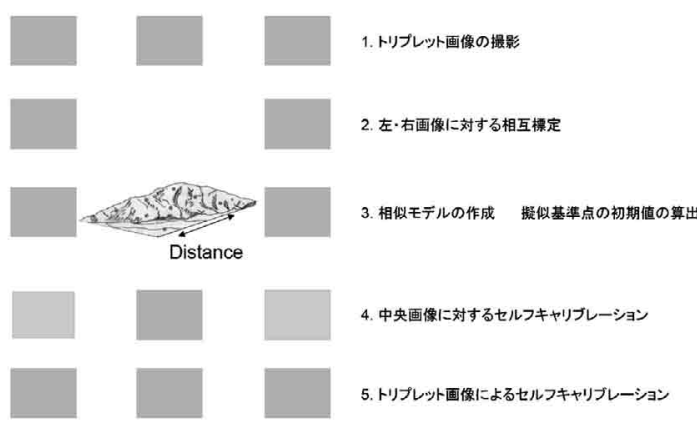

図 2 キャリブレーションの流れ

\section{1 キャリブレーション手順}

図 2 はキャリブレーション手順を示したものである が，取得された擬似基準点の三次元座標と各カメラの 内部・外部標定要素を初期值とし, これらの未知量を 同時に調整するものであり，本研究で提案するカメラ キャリブレーションにおける未知量は左, 中央, 右力 メラに対する外部標定要素18個 \{位置 $\left(X_{0 \mathrm{~L}}, Y_{0 \mathrm{~L}}, Z_{\mathrm{oL}}\right)$, $\left(X_{0 \mathrm{c}}, Y_{\mathrm{OC}}, Z_{\mathrm{OC}}\right),\left(X_{\mathrm{OR}}, Y_{\mathrm{OR}}, Z_{\mathrm{OR}}\right)$, 姿勢 $\left(\omega_{\mathrm{OL}}, \kappa_{0 \mathrm{~L}}, \varphi_{\mathrm{OL}}\right),\left(\omega_{\mathrm{oc}}\right.$, $\left.\left.\kappa_{0 \mathrm{c}}, \varphi_{0 \mathrm{c}}\right), \quad\left(\omega_{0 \mathrm{R}}, \kappa_{0 \mathrm{R}}, \varphi_{0 \mathrm{R}}\right)\right\}$ および 3 つのカメラに共通な 内部標定要素 7 個 $\left\{\right.$ 焦点距離 $f$, 主点の位置 $x_{0}, y_{0}, レ$ ンズ歪係数 $K_{1}, K_{2}$, 画素座標から画像座標への変換係 数 $a, b\}$ と擬似基準点 $n$ 点に対する三次元座標 $\left(X_{i}\right.$, $\left.Y_{i}, Z_{i}\right)$ の $3 n$ 個, 合計 $25+3 n$ 個となるが, 原点および $\mathrm{X}$ 軸を規定する擬似基準点を配置するため, これらの 擬似基準点座標 $\mathrm{P}_{0}(0,0,0), \mathrm{P}_{1}\left\{X_{1}(=D), 0, Z_{1}\right\}$ に抒い て, $Z_{1}$ は既知量 (例えば, 点 $\mathrm{P}_{1}$ は原点と同じ平面上の 点とすると $\left.Z_{1}=0\right)$ とすると未知量は $X_{1}$ を除く 5 個減 少し, 合計 $25+3 n-5$ 個となる。

いっぽう，これら未知量に対して 3 枚の画像に共通 な擬似基準点より得られる共線条件式と距離に対寸る 観測方程式が条件式となり, 各未知量は距離の拘束の 下に最小二乗法の原理にしたがって式(2)を最小とする 值として算出されることになる。なお，この場合 $25+3 n-5<6 n+1$ より， 7 点以上の擬似基準点が必 要となるが，本研究ではソフト開発を行なうに当たり 擬似基準点数の影響を無視するために 13 点を擬似基準 点とした。

$H=\left[p_{1}\left(d x^{2}+d y^{2}\right)\right]+p_{2}\left[d D^{2}\right] \Rightarrow \min$

ここに, [ ] : 総和記号, $d x, d y$ : 画像座標に対する 補正量, $d D$ : 距離に対する補正量, $p_{1}, p_{2}$ : 画像及び距 離の測定值に対する重み（本研究では $p_{1}=p_{2}=1$ ) 
なお，レンズ歪み補正量を放射方向 5 次多項式モデ ル $\left(\Delta_{\mathrm{rad}}\right)$ で表すとすると, $x, y$ 方向の補正量は次式で 表すこととなる。

$\left.\begin{array}{l}\Delta \Delta_{\mathrm{rad}}=K_{1} r^{3}+K_{2} r^{5} \\ \Delta x_{\mathrm{rad}}=\left(\Delta_{\mathrm{rad}} / r\right) x \\ \Delta y_{\mathrm{rad}}=\left(\Delta_{\mathrm{rad}} / r\right) y\end{array}\right\}$

ここに, $r=\sqrt{\left(x^{2}+y^{2}\right)}, x, y$ : 補正前の像点の画像座 標, $K_{1}, K_{2}$ : 放射方向レンズ歪み係数

\section{3.エピポーラ調整}

図 2 に示したトリプレット画像によるカメラキャリ ブレーション手法 (3DiVision) では 2 点間距離は縦ま たは横に設置することは可能であるが，簡便性から距 離の計測は 1 個所のみであり, X 軸方向に行なう場合 が一般的であるため, Y 軸方向の縮尺は X 軸方向と比 較して低い精度となる。また，縮尺を決定する要因の 一つは焦点距離であり，EXIF 情報から取得される焦 点距離（公称值）を使用した場合でも上記の理由によ り $\mathrm{Y}, \mathrm{Z}$ 座標の初期值の精度は低いものとなる。した がって, 3DiVisionに打ける課題は擬似基準点の初期 值の内, $\mathrm{Y}, \mathrm{Z}$ 座標の初期值の精度を如何に改善する か，言い換えれば如何にして質の高い擬似基準点座標 が算出される焦点距離を与えるかという問題に帰着す る。

そこで, 本研究では図 2 の 2 に抒ける左右画像の相 互標定の際に左・中央拈よび中央・右のステレオペア の組み合わせについてそれぞれ相互標定を行なった 後, 左右画像に打ける同じ擬似基準点に対するエピ ポーララインが中央画像の同一擬似基準点において交 わるという拘束条件式を導入し, 焦点距離の初期值を 以下のように算出することとする。

すなわち，

$q_{1}=a_{31,1} \cdot x_{1}+a_{32,1} \cdot y_{1}-a_{33,1} \cdot f$

$r_{1}=a_{21,1} \cdot x_{1}+a_{22,1} \cdot y_{1}-a_{23,1} \cdot f$

$q_{4}=a_{31,4} \cdot x_{4}+a_{32,4} \cdot y_{4}-a_{33,4} \cdot f$

$r_{4}=a_{21,4} \cdot x_{4}+a_{22,4} \cdot y_{4}-a_{23,4} \cdot f$

ここに, $a_{i j, 1}$ : 左画像における回転パラメー夕, $a_{i j, 2}$ : 右画像 (中央画像)に扔ける回転パラメー夕, $a_{i j, 3}$ : 左 画像 (中央画像)に打ける回転パラメー夕， $a_{i j, 4}$ : 右画
像に扔ける回転パラメー夕， $\left(x_{1}, y_{1}\right)$ : 左画像における 擬似基準点の画像座標， $\left(x_{4}, y_{4}\right)$ : 右画像に打ける擬似 基準点の画像座標, $f:$ 焦点距離 (公称值)

とすると, 左画像から中央画像拈よび右画像から中央 画像に対するに対するエピポーララインは式(6)となる から,

$$
\begin{aligned}
\left(q_{1} \cdot a_{21,2}-r_{1} \cdot a_{31,2}\right) x+\left(q_{1} \cdot a_{22,2}-r_{1} \cdot a_{32,2}\right) y & \\
& -\left(q_{1} \cdot a_{23,2}-r_{1} \cdot a_{33,2}\right) f=0 \\
\left(q_{4} \cdot\right. & \left.\cdot a_{21,3}-r_{4} \cdot a_{31,3}\right) x+\left(q_{4} \cdot a_{22,3}-r_{4} \cdot a_{32,3}\right) y \\
& -\left(q_{4} \cdot a_{23,3}-r_{4} \cdot a_{33,3}\right) f=0
\end{aligned}
$$

エピポーララインの交点に対する座標は次式となる。

$$
\begin{aligned}
& x= \frac{\left(B_{1} C_{3}-B_{3} C_{1}\right)}{\left(A_{1} B_{3}-A_{3} B_{1}\right)} \\
& y= \frac{\left(C_{1} A_{3}-C_{3} A_{1}\right)}{\left(A_{1} B_{3}-A_{3} B_{1}\right)} \\
& \text { ここに, } \\
& A_{1}=\left(q_{1} \cdot a_{21,2}-r_{1} \cdot a_{31,2}\right), \quad B_{1}=\left(q_{1} \cdot a_{22,2}-r_{1} \cdot a_{32,2}\right), \\
& \quad C_{1}=-\left(q_{1} \cdot a_{23,2}-r_{1} \cdot a_{33,2}\right) f \\
& A_{3}=\left(q_{4} \cdot a_{21,3}-r_{4} \cdot a_{31,3}\right), \quad B_{3}=\left(q_{4} \cdot a_{22,3}-r_{4} \cdot a_{32,3}\right), \\
& \quad C_{3}=-\left(q_{4} \cdot a_{23,3}-r_{4} \cdot a_{33,3}\right) f
\end{aligned}
$$

そこで,

$Q=\left(A_{1} B_{3}-A_{3} B_{1}\right), \quad R=\left(B_{1} C_{3}-B_{3} C_{1}\right)$,

$$
S=\left(C_{1} A_{3}-C_{3} A_{1}\right)
$$

とすると次式が得られる。

$$
\begin{aligned}
& F \equiv Q x-R=0 \\
& G \equiv Q y-S=0
\end{aligned}
$$

ところで, 3DiVisionにおけるレンズ歪みモデルは 放射方向 5 次多項式モデル (5R) であるが，工ピポー ラ調整に扔いてはすでに相互標定がされている画像の 画像残差の精度を改善する必要上, 接線歪みも考慮し た 5 次放射方向歪み十接線方向歪みモデル (5RD) と する。したがって，5次放射方向歪みと接線方向歪み モデル（5RD）を考慮した場合, 接線歪み補正量を $\Delta x_{\mathrm{tan}}, \Delta y_{\mathrm{tan}}$, 総補正量を $\Delta x\left(\Delta x_{\mathrm{rad}}+\Delta x_{\mathrm{tan}}\right), \Delta y\left(\Delta y_{\mathrm{rad}}\right.$ $\left.+\Delta y_{\tan }\right)$ とするとレンズ歪み補正後の $x, y$ 座標 $(\bar{x}, \bar{y})$ は,

$$
\begin{aligned}
& \bar{x}=x+\Delta x \\
& \bar{y}=y+\Delta y \\
& \text { ここに, } \Delta x_{\tan }=P_{1}\left(r^{2}+2 x^{2}\right)+2 P_{2} x y, \Delta y_{\tan }=P_{2}\left(r^{2}\right.
\end{aligned}
$$


$\left.+2 y^{2}\right)+2 P_{1} x y, r=\sqrt{\left(x^{2}+y^{2}\right)}, x, y:$ 補正前の画像座 標, $P_{1}, P_{2}$ : 接線方向歪み係数

また，画像座標と画面座標との関係式に次式を適用す ると（Faugeras \& Toscani, 1987),

$u=u_{0}+a x+b y$

$v=v_{0}+c y$

ここに, $(u, v)$ : 画面座標 $(\mathrm{pixel}),\left(u_{0}, v_{0}\right)$ : 主点位置 (pixel), $(x, y)$ : 画像座標 $(\mathrm{mm}), a, c$ : スケールファ ク夕, $b$ : 世九断係数

であるから各交点に対する式(9)は次式となる。

$$
\begin{aligned}
F & \equiv\left(u_{i}-u_{0}\right) \cdot Q_{i}-\frac{1}{\left(1+K_{1} r_{i}^{2}+K_{2} r_{i}^{4}+2 P_{1} x+2 P_{2} y\right)} \\
& \cdot\left\{\left(a R_{i}+b S_{i}\right)-r^{2}\left(a P_{1}+b P_{2}\right)\right\}=0 \\
G & \equiv\left(v_{i}-v_{0}\right) \cdot Q_{i}-\frac{1}{\left(1+K_{1} r_{i}{ }^{2}+K_{2} r_{i}^{4}+2 P_{1} x+2 P_{2} y\right)} \\
& \cdot c\left(S_{i}-r^{2} P_{2}\right)=0
\end{aligned}
$$

式(12)における未知量を焦点距離 $(f)$, 放射方向レン ズ歪み $\left(K_{1}, K_{2}\right)$, 接線方向レンズ歪み $\left(P_{1}, P_{2}\right)$ とし, 式 (12)をテーラ展開し最小二乗法の原理にしたがって算出 される最小解を用いて算出される交点座標と中央画像 上の画像座標との残差の 2 乗和と未知量に対する内的 精度の 2 乗和とを用いて $4.1 て ゙$ 述べる手法により焦点 距離の初期值を更新する。

\section{4．精度検証実験}

\section{1 実験概要}

ここでは, エピポーラ調整を導入した3DiVisionの 有効性を検討するために，検証用テストターゲット (H：480mm, W：640mm, D：20mm)に対して表 1 に示す民生用デジタルカメラを使用して精度検証実験 を行なった。撮影は各カメラに対する画像縮尺がほぼ 一定となるように撮影距離（カメラからターゲット間 の距離）を調整し, 左右画像に対する基線比 0.34 とし て各カメラに対してトリプレット撮影を 5 回ずつ行な うものであるが，各画像は撮影ごとにレンズを焦点距 離のテレ端に移動させた後，ワイド端に戻して取得さ れたものである。また，ターゲットの大きさ（直径） は $20 \mathrm{~mm}$, ターゲット間隔は $40 \mathrm{~mm}$, ターゲットの中央 3 列は高さ $20 \mathrm{~mm}$ であり, 各円形ターゲットの加工精 度は土0.05mm である。精度検証は図 3 中の白丸で印 した13点を擬似基準点としてカメラキャリブレーショ ンを実施した後，黒枠で印した検証点86点に対する三 次元座標を算出して評価を行なうこととする。なお， これらの点の画素座標は撮影した画像に二值化処理を

\begin{tabular}{|c|c|c|c|c|c|c|c|}
\hline $\begin{array}{l}\text { Maker } \\
\text { 機種名 }\end{array}$ & $\begin{array}{c}\text { SONY } \\
\text { CyberShot } \\
\text { DSC-T10 }\end{array}$ & $\begin{array}{c}\text { SONY } \\
\text { CyberShot } \\
\text { DSC-N1 }\end{array}$ & $\begin{array}{l}\text { Nikon } \\
\text { COOLPIX } \\
\text { S500 }\end{array}$ & $\begin{array}{l}\text { Nikon } \\
\text { COOLPIX } \\
\text { S700 }\end{array}$ & $\begin{array}{l}\text { Nikon } \\
\text { COOLPIX } \\
\text { S710 }\end{array}$ & $\begin{array}{c}\text { Canon } \\
\text { IXY DIGITAL } \\
1000\end{array}$ & $\begin{array}{c}\text { Canon } \\
\text { IXY DIGITAL } \\
2000 \text { IS }\end{array}$ \\
\hline 画素数(Megapixel) & 7.2 & 8.1 & 7.1 & 12.1 & 14.5 & 10 & 12.1 \\
\hline 撮像素子 & $1 / 2.5 " \mathrm{CCD}$ & $1 / 1.8 " \mathrm{CCD}$ & $1 / 2.5 " \mathrm{CCD}$ & 1/1.72"CCD & 1/1.72"CCD & $1 / 1.8 " \mathrm{CCD}$ & $1 / 1.7 " \mathrm{CCD}$ \\
\hline 解像度 & $3072 \times 2304$ & $3264 \times 2448$ & $3072 \times 2304$ & $4000 \times 3000$ & $4352 \times 3264$ & $3648 \times 2736$ & $4000 \times 3000$ \\
\hline 焦点距離(mm) & 6.33 & 7.9 & 5.7 & 7.9 & 6.0 & 7.7 & 7.7 \\
\hline 焦点距離 $(\mathrm{mm})(35 \mathrm{~mm}$ 換算) & 38 & 38 & 35 & 37 & 28 & 37 & 36 \\
\hline 撮影距離(mm) & 893 & 866 & 801 & 851 & 665 & 876 & 876 \\
\hline Maker & Panasonic & OLYMPUS & CASIO & Kodak & PENTAX & FUJIFILM & Canon \\
\hline 機種名 & $\begin{array}{c}\text { LUMIX } \\
\text { DMC-FX9 }\end{array}$ & $\mu 810$ & $\begin{array}{c}\text { EXLIM } \\
\text { EX-Z1000 }\end{array}$ & $\begin{array}{c}\text { EasyShare } \\
\text { V1003 }\end{array}$ & Optio A40 & $\begin{array}{c}\text { FinePix } \\
\text { F50fd }\end{array}$ & EOS 50D* \\
\hline 画素数(Megapixel) & 6 & 8 & 10.1 & 10 & 12 & 12 & 15 \\
\hline 撮像素子 & $1 / 2.5 " \mathrm{CCD}$ & $1 / 1.8 " \mathrm{CCD}$ & $1 / 1.8 " \mathrm{CCD}$ & 1/1.8"CCD & $1 / 1.7 " \mathrm{CCD}$ & $1 / 1.6 ” \mathrm{CCD}$ & $22.3 \times 14.9 \mathrm{~mm}$ \\
\hline 解像度 & $2816 \times 2112$ & $3264 \times 2448$ & $3648 \times 2736$ & $3648 \times 2736$ & $4000 \times 3000$ & $4000 \times 3000$ & $4752 \times 3168$ \\
\hline 焦点距離(mm) & 5.8 & 7.4 & 7.9 & 7.5 & 7.9 & 8.0 & 24 \\
\hline 焦点距離 (mm) (35mm 換算) & 35 & 35 & 38 & 36 & 37 & 35 & 38.4 \\
\hline 撮影距離(mm) & 845 & 832 & 875 & 827 & 865 & 829 & 1086 \\
\hline
\end{tabular}
施した後, 面積重心として算出したものであり, 本研 究での結果は 5 回測定の平均值である。

表 1 カメラ諸元

*Lens : Canon EF 24-105mm F4L IS USM 


\section{2 焦点距離の更新}

3DiVision においては擬似基準点の三次元座標の初 期值は相互標定の結果より得られる相似モデルに対し て 2 点間の距離を用いた相似変換により算出してい る。したがって, 擬似基準点の三次元座標の初期值は 焦点距離の值に影響されることとなる。しかしながら， 民生用デジタルカメラの場合には EXIF 情報から取 得される焦点距離の公称值は概略值であるため, 3DiVision における精度改善のためには高品位な焦点 距離の初期值を知ることが必要となる。

そこで, 本研究では EXIF 情報より得られる焦点距 離の前後 $0.5 \mathrm{~mm}$ の区間において, 画像座標と中央画像 上の画像座標との残差の 2 乗和を各未知量に対する内 的精度の 2 乗和の平方で正規化したものの重心位置に 対応する值を焦点距離の初期值 (公称值)に代わる值と する。

なお，ここでの 2 点間距離は図 3 に示すテストター ゲットにおいて下段の左右の 2 点間距離とし，その值

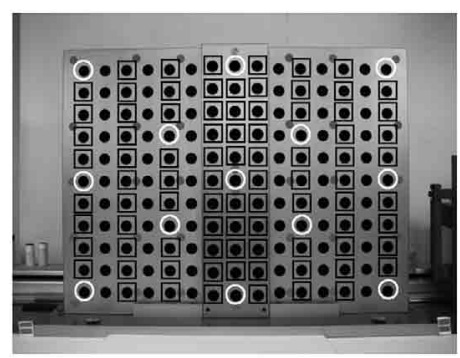

図 3 テストターゲット

表 2 エピポーラ調整前後における画像残差 $(f=7.9 \mathrm{~mm})$

\begin{tabular}{rrrr}
\hline \multicolumn{2}{c}{ 調整前画像残差 } & \multicolumn{2}{c}{ 調整後画像残差 } \\
$x$ (pixel) & $y$ (pixel) & $x$ (pixel) & $y$ (pixel) \\
\hline-30.305 & 0.038 & -18.560 & 0.079 \\
15.110 & 0.370 & 15.203 & 0.315 \\
3.144 & -0.122 & -3.969 & -0.147 \\
12.684 & -0.370 & 7.951 & -0.348 \\
16.437 & 0.340 & 18.295 & 0.356 \\
3.473 & -0.056 & 2.275 & -0.036 \\
-12.943 & 0.001 & -9.698 & 0.028 \\
-2.505 & 0.118 & 1.192 & 0.044 \\
5.333 & -0.088 & 4.285 & -0.022 \\
32.188 & 0.158 & -3.730 & -0.160 \\
-27.603 & -0.398 & -7.959 & -0.159 \\
-31.542 & -0.308 & -7.387 & -0.038 \\
16.316 & 0.323 & 2.108 & 0.097 \\
\hline 精度 & 69.727 & 精度 & 35.285 \\
\hline
\end{tabular}

は560mm である。

表 2 は民生用デジタルカメラ（N1）の第 1 セット目 のデー夕に対する焦点距離 $7.9 \mathrm{~mm}$ (公称值)における エピポーラ調整前後の擬似基準点13点に対する画像残 差抢よび精度（画像残差の 2 乗和の平方）を示したも のである。表 2 よりエピポーラ調整が有効に機能して いることが確認される。なお，表 2 において $y$ 座標の 画像残差が小さい理由はすでに相互標定が行なわれて いるためである。

いっぽう, 表 3 は焦点距離の公称值 $(\mathrm{f}=7.9 \mathrm{~mm})$ に 代わり更新焦点距離（ $\mathrm{f}=8.25 \mathrm{~mm} ）$ を初期值として各 擬似基準点 $X, Y, Z$ に対する外的精度と以下の標準 精度で擬似基準点に対する精度を検討したものであ る。なお，外的精度とは各擬似基準点 $X, Y, Z$ に対す る RMS 誤差であり，ここでの標準精度とは各擬似基 準点 $X, Y, Z$ に対する内的精度（Beyer，1991）をそ れぞれ $\hat{\sigma}_{X}, \hat{\sigma}_{Y}, \hat{\sigma}_{Z}$ として次式より算出される值であ る。

$\hat{\sigma}=\sqrt{\sum \hat{\sigma}_{X}{ }^{2}+\sum \hat{\sigma}_{Y}{ }^{2}+\sum \hat{\sigma}_{Z}{ }^{2}}$

ここに, $\hat{\sigma}_{X}, \hat{\sigma}_{Y}, \hat{\sigma}_{Z}$ : 各擬似基準点 $X, Y, Z$ に対する 内的精度

表 3 より僅かであるが擬似基準点の精度の向上が確 認される。したがって, 提案手法であるエピポーラ調 整を行なうことにより3DiVisionによる多少の精度改 善が期待される。

\section{3 精度検証結果}

ここでは提案手法の妥当性を検討する。図 4 は各力 メラに対する計測精度を示したものである。なお，計 測精度とは近接デジタル写真測量において広く利用さ れている一つの指標であり, 平均標準誤差 $\left(\sigma_{c}\right)$ および 計測対象の大きさ $(D)$ から次式より $\sigma_{c} / D$ として算出 される值である（Fraser，1996）。

$\frac{\sigma_{c}}{D}=\frac{\sqrt{\left(\sigma_{X}{ }^{2}+\sigma_{Y}{ }^{2}+\sigma_{Z}{ }^{2}\right) / 3}}{\sqrt{D X^{2}+D Y^{2}+D Z^{2}}}$

ここに, $\sigma_{c}$ : 平均標準誤差, $\sigma_{X, Y, Z}$ : 検証点 86 点に対す る $\mathrm{X}, \mathrm{Y}, \mathrm{Z}$ 座標の平均二乗䛊差,

$D$ : 対象物の大きさ, $D X, D Y, D Z$ : 対象物の $\mathrm{X}, \mathrm{Y}$, $Z$ 方向の大きさ

図 4 より幾つかの機種においては多少のエピポーラ 調整の効果が認められるが, 多くの機種においては工 
表 3 擬似基準点の精度（N1）

\begin{tabular}{|c|c|c|c|c|c|c|c|c|}
\hline \multicolumn{3}{|c|}{ 三次元座標 (最確値) } & \multicolumn{3}{|c|}{ 三次元座標 (公称値, $\mathrm{f}=7.9 \mathrm{~mm}$ ) } & \multicolumn{3}{|c|}{ 三次元座標 (更新值, $\mathrm{f}=8.25 \mathrm{~mm}$ ) } \\
\hline $\mathrm{X}(\mathrm{mm})$ & $\mathrm{Y}(\mathrm{mm})$ & $Z(\mathrm{~mm})$ & $\mathrm{X}(\mathrm{mm})$ & $\mathrm{Y}(\mathrm{mm})$ & $\mathrm{Z}(\mathrm{mm})$ & $\mathrm{X}(\mathrm{mm})$ & $\mathrm{Y}(\mathrm{mm})$ & $Z(\mathrm{~mm})$ \\
\hline 0 & 0 & 0 & -0.536 & -0.116 & -0.627 & -0.515 & -0.101 & -0.581 \\
\hline 560 & 0 & 0 & 560.019 & 0.271 & 1.124 & 560.054 & 0.243 & 1.054 \\
\hline 0 & 400 & 0 & -0.888 & 401.700 & 15.659 & -1.232 & 401.218 & 15.631 \\
\hline 280 & 0 & 20 & 280.976 & -4.856 & 14.236 & 280.873 & -5.050 & 13.977 \\
\hline 0 & 200 & 0 & -2.855 & 200.294 & 6.330 & -2.985 & 199.968 & 6.382 \\
\hline 280 & 200 & 20 & 281.527 & 198.621 & 22.592 & 281.371 & 198.352 & 22.310 \\
\hline 560 & 200 & 0 & 563.190 & 199.133 & 8.408 & 563.289 & 198.945 & 8.322 \\
\hline 280 & 400 & 20 & 281.919 & 403.025 & 31.341 & 281.710 & 402.883 & 31.030 \\
\hline 560 & 400 & 0 & 561.984 & 398.864 & 17.768 & 562.193 & 398.711 & 17.594 \\
\hline 160 & 120 & 0 & 158.248 & 118.223 & -0.606 & 158.213 & 118.095 & -0.100 \\
\hline 400 & 120 & 0 & 403.701 & 118.027 & 0.299 & 403.546 & 117.926 & 0.742 \\
\hline 160 & 280 & 0 & 158.369 & 281.930 & 6.195 & 158.244 & 281.507 & 6.661 \\
\hline 400 & 280 & 0 & 404.225 & 281.120 & 7.037 & 404.075 & 280.792 & 7.442 \\
\hline
\end{tabular}

外的精度 $(\mathrm{mm})$ /内的精度 $(\mathrm{mm}) \quad 32.397 / 4.698$

$32.371 / 4.248$

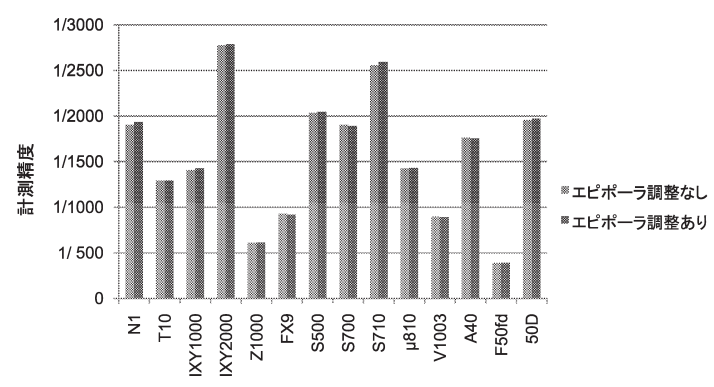

図 4 計測精度

ピポーラ調整の効果は認められなかった。この理由と しては，最適な焦点距離の初期值が公称值の前後 0.5 $\mathrm{mm}$ の区間に存在しないこと，および焦点距離の值が 小さいため焦点距離の更新が擬似基準点座標に大きく 反映されなかったためであると推測される。この推測 については次項以降においてさらに考察する。また, F50fd の精度が低い理由としては正方形素子センサー を用いていないためと推測される。

\subsection{DiVision の応用}

本研究で提案したエピポーラ調整付き $3 \mathrm{DiVision} は$ 高精度写真測量を可能とするものではないが，簡便的 写真測量においては有効な手法であると期待される。 そこで，3DiVisionによる簡便的写真測量を検証する ため, ギリシャ古代都市フィガリアにおける城壁に対 してトリプレット撮影を行なった。困 5 は計測対象の
城壁であり, 中央画像の左右に三脚に取り付けられた 円形ターゲットが確認されるが，この 2 点間距離が計 測された。図中のその他の円形ターゲットは検証用 ターゲットであり，これらの夕ーゲットの三次元座標 はトータルステーションで計測されているが，距離計 測用ターゲットの三次元座標は計測されていないため 座標に対する精度検証を行なうことは不可能である。 そこで，ここでは3DiVisionによるキャリブレーショ ン後に算出される各検証点の座標を用いて算出される 各検証点間の距離とトータルステーションで計測され た三次元座標をから算出される距離との比較を行なう こととし, 図 6 に示す 3 測線に対する結果が表 4 であ る。なお，ここで使用したカメラは EOS 50D(1500万 画素， $\mathrm{f}=10 \mathrm{~mm}$ ) であり，擬似基準点数は 17 点，撮影 距離は凡そ6.9m である。また， 2 点間距離 $(10.1672$ m) の計測はレーザー距離計（Leica，DISTO ${ }^{\mathrm{Tm}} \mathrm{D} 3$, $\pm 1.0 \mathrm{~mm})$ により行なった。

困 6 はオルソ画像であり, 図 7 はC Canny オペレータ により抽出したエッジ画像である。表 4 よりまず気付 くことは使用カメラの焦点距離の值 $(\mathrm{f}=10 \mathrm{~mm})$ は小 さいにもかかわらずエピポーラ調整の効果が認められ ることである。このことは焦点距離の值が小さくても 撮影距離が長ければエピポーラ調整の効果があるもの と推測される。

いっぽう，通常文化財の分野では $1 / 50$ あいは $1 /$ 20 程度の平面図が一般的であるが, 図面上 $0.3 \mathrm{~mm}$ 程度 の精度を考えた場合3DiVisionの結果は $1 / 50$ の精度 
を満たしていることが確認されるが，エピポーラ調整 を行なうことにより1/20の精度もほぼ満足されるこ とが確認される。

また，図 7 に示したエッジ図は素図として利用され ることを考慮すると3DiVision は簡便的写真測量の分 野に打いて十分有効な手法であると期待される。

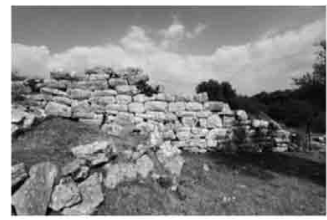

(a) 左画像

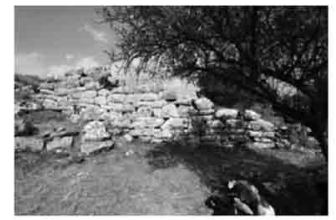

(b) 右画像

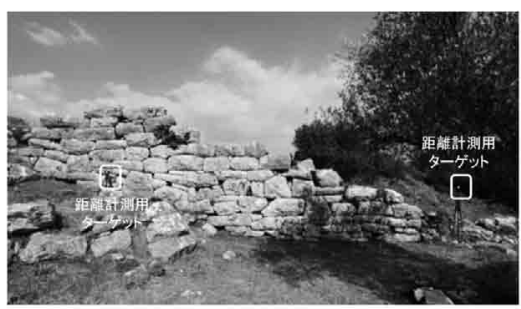

(c) 中央画像

図 5 計測対象

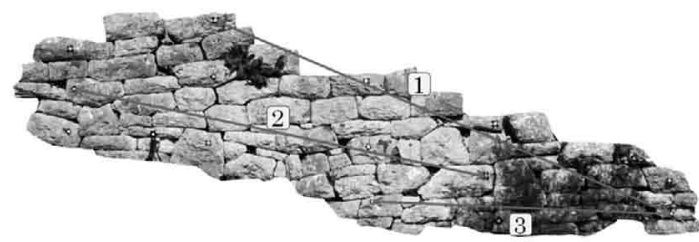

図 6 オルソ画像

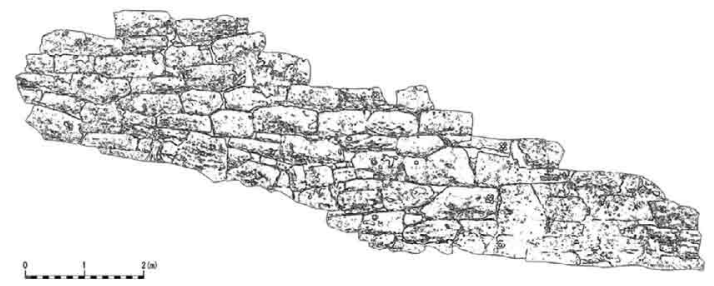

図 7 エッジ画像

表 4 計測結果

\begin{tabular}{|c|c|c|c|}
\hline \multirow[b]{2}{*}{ 計測区間 } & \multirow[b]{2}{*}{$\begin{array}{c}\text { 実測值 } \\
(\mathrm{mm}) \\
\mathrm{TS}\end{array}$} & \multicolumn{2}{|c|}{ 差 (実測值-3DiVision計測值) (mm) } \\
\hline & & $\begin{array}{c}\text { エピポーラ } \\
\text { 調整なし } \\
\mathrm{f}=10 \mathrm{~mm}\end{array}$ & $\begin{array}{l}\text { エピポーラ } \\
\text { 調整あり } \\
\mathrm{f}=9.83 \mathrm{~mm}\end{array}$ \\
\hline 1 & 8456.7 & -9.5 & -7.1 \\
\hline 2 & 7217.7 & 10.9 & -3.2 \\
\hline 3 & 5125.0 & -4.6 & 1.9 \\
\hline
\end{tabular}

\section{6. 長焦点レンズを用いた検証}

前節において焦点距離が短い場合にはエピポーラ調 整の効果が小さいこと, 撮影距離が長くなれば工ポ ピーラ調整の効果が大であると推定されたが, ここで はマクロレンズ (Canon, EF100mm f/2.8 Macro USM）を用いてこの推定を検証する。なお，使用カメ ラは前節と同じ EOS 50D である。

図 8 はマクロレンズ用に使用する小型テストター ゲット $(\mathrm{H}: 100 \mathrm{~mm}, \mathrm{~W}: 100 \mathrm{~mm})$ であり, ターゲッ トの大きさ (直径) は $10 \mathrm{~mm}$, ターゲット間隔は $20 \mathrm{~mm}$, ターゲット中央下段 2 点（図中四角で囲まれたター ゲット)に対する高さは $10 \mathrm{~mm}$ である。各円形ターゲッ トの加工精度は図 3 と同様に $\pm 0.05 \mathrm{~mm}$ であり, ここ での擬似基準点数は図中の白丸と四角で印した 8 点と し，擬似基準点以外の17点を検証点とする。また， 2 点間距離は図 8 において下段の左右間の距離とし, そ の值は $80 \mathrm{~mm}$ である。

なお，3DiVisionにおけるレンズ歪みモデルは放射 方向 5 次多項式モデルを採用しているが, マクロレン ズを用いる場合，放射方向 3 次多項式モデルで十分な 計測精度が得られることが報告されているため（柳・ 近津, 2009), ここでの検証におけるレンズ歪みモデル は放射方向 3 次多項式モデルを採用する。また, エピ ポーラ調整における未知量は焦点距離 $f$ と放射方向 歪み $K_{1}$ であり，探索区間は焦点距離 $100 \mathrm{~mm}$ の前後 10 $\mathrm{mm}$ とする。

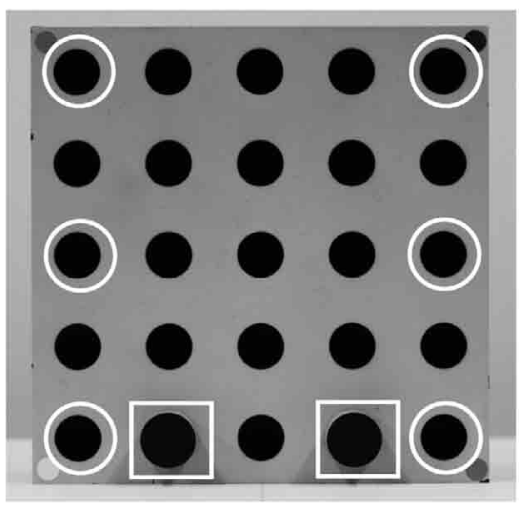

図 8 マクロレンズ用テストターゲット 


\section{1 精度評価}

表 5 は第 1 セット目のデータに対する焦点距離 $100.0 \mathrm{~mm}$ (公称值)におけるエピポーラ調整前後の擬 似基準点に対する画像残差および精度（画像残差の 2 乗和の平方）を示したものである。

表 5 より，エピポーラ調整がマクロレンズの場合に も有効に機能していることが確認される。

次に, 民生用デジタルカメラの場合と同様に焦点距 離の違いによる擬似基準点の三次元座標に対する初期 值の検証を行なう。

表 6 は公称值を使用した場合と更新後の焦点距離を 使用した場合に対する擬似基準点座標と精度である。 表 6 よりマクロレンズの場合には擬似基準点座標の精 度, 特に Y 座標に対する精度が良好に改善されている ことが確認される。この理由としてはマクロレンズ $(\mathrm{f}=100 \mathrm{~mm})$ の焦点距離は民生用デジタルカメラと比 較してもかなり大きな值であるため, 焦点距離の值の 変動が擬似基準点に与える影響は大きく，焦点距離の 更新が擬似基準点座標に効率的に反映されたためと考

表 5 画像残差 $(f=100 \mathrm{~mm})$

\begin{tabular}{rrrr}
\hline \multicolumn{2}{c}{ 調整前画像残差 } & \multicolumn{2}{c}{ 調整後画像残差 } \\
$x$ (pixel) & $y$ (pixel) & $x$ (pixel) & $y$ (pixel) \\
\hline 26.170 & 2.482 & -1.829 & 0.003 \\
-34.026 & 2.347 & 1.914 & -0.018 \\
-0.456 & 1.718 & -0.519 & -0.025 \\
4.099 & -0.624 & 4.092 & -0.042 \\
-2.661 & -0.569 & -3.842 & 0.029 \\
1.772 & -3.434 & -6.522 & 0.028 \\
-3.817 & -3.459 & 0.752 & 0.016 \\
0.919 & 1.732 & 0.079 & -0.006 \\
\hline
\end{tabular}

精度 43.902 (pixel) 精度 9.050 (pixel)

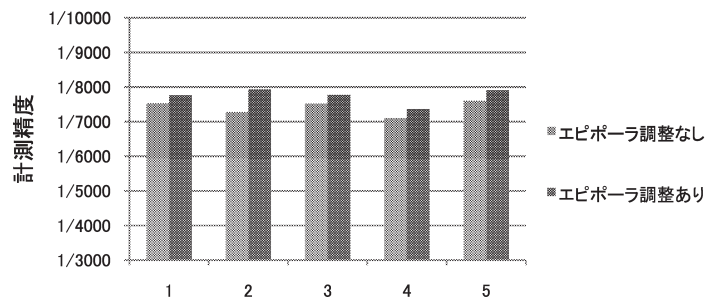

図 9 計測精度（マクロレンズ：EOS50D）

えられる。

特に，3DiVision では擬似基準点座標の算出におい てY座標の精度改善が課題であったが, 表 6 よりエピ ポーラ調整の導入によりこの課題は解決され, 本研究 の目標が達成されていることが確認される。

いっぽう，図９はマクロレンズ（EOS 50D）に対す る 5 個のデータセットに対する計測精度を示したもの である。

図 9 より，まず注目できることはマクロレンズ （EOS 50D）の場合には3DiVisionはエピポーラ調整 を考慮しなくても, 極めて高い精度での三次元計測が 可能であることが理解される。また，民生用カメラの 場合にはエピポーラ調整の効果は小さかったのに対し て, マクロレンズの場合にはエピポーラ調整が有効で あることが確認された。この結果からも表 6 における 検証結果と同様に焦点距離の更新が直接擬似基準点座 標に効率的に反映されたと推測できる。

特に, 3DiVision では相互標定の結果が得られる相 似モデルに対して 2 点間距離を用いて擬似基準点座標 の初期值を算出するため, 距離設定が行なわれない軸 方向に対する座標精度の低下が課題であったが, エピ ポーラ調整の導入によりこの課題は解決されることが 確認された。

表 6 擬似基準点の精度（マクロレンズ：EOS50D）

\begin{tabular}{rrrrrrrrr}
\hline \multicolumn{3}{c}{ 三次元座標(最確值) } & \multicolumn{2}{c}{ 三次元座標(公称值, $\mathrm{f}=100 \mathrm{~mm})$} & \multicolumn{2}{c}{ 三次元座標 $($ 更新值, $\mathrm{f}=109.258 \mathrm{~mm})$} \\
$\mathrm{X}(\mathrm{mm})$ & $\mathrm{Y}(\mathrm{mm})$ & $\mathrm{Z}(\mathrm{mm})$ & $\mathrm{X}(\mathrm{mm})$ & $\mathrm{Y}(\mathrm{mm})$ & $\mathrm{Z}(\mathrm{mm})$ & $\mathrm{X}(\mathrm{mm})$ & $\mathrm{Y}(\mathrm{mm})$ & $\mathrm{Z}(\mathrm{mm})$ \\
\hline 0 & 0 & 0 & -0.041 & -0.001 & -0.017 & -0.042 & -0.001 & -0.016 \\
80 & 0 & 0 & 80.040 & 0.001 & 0.025 & 80.041 & 0.001 & 0.023 \\
0 & 80 & 0 & 0.017 & 82.411 & 2.206 & 0.022 & 80.776 & 2.249 \\
20 & 0 & 10 & 19.884 & -0.117 & 11.411 & 19.842 & -0.206 & 10.473 \\
60 & 0 & 10 & 60.032 & -0.123 & 11.596 & 60.079 & -0.213 & 10.643 \\
0 & 40 & 0 & -0.022 & 41.215 & 1.094 & -0.020 & 40.395 & 1.116 \\
80 & 40 & 0 & 80.081 & 41.216 & 1.156 & 80.092 & 40.395 & 1.174 \\
80 & 80 & 0 & 80.110 & 82.394 & 2.287 & 80.131 & 80.758 & 2.325 \\
\hline
\end{tabular}

外的精度 $(\mathrm{mm}) /$ 内的精度 $(\mathrm{mm})$

$5.633 / 0.574$

$3.949 / 0.546$ 


\section{7. 結 論}

本研究では簡便的デジタル写真測量の実用化を目指 し, 地上基準点を必要とせず, 且つ事前に内部標定要 素の算出を必要としないカメラキャリブレーション手 法を提案し, エピポーラ調整を用いた精度改善につい て検討を行なった。その結果, 焦点距離が短い民生用 デジタルカメラに対してはエピポーラ調整の効果が小 さいが焦点距離が長いカメラに対してはエポピーラ調 整の効果が大であること, および焦点距離が短いカメ ラの場合でも撮影距離を大きく取ることにより焦点距 離の長いカメラを使用する場合と同じ効果によりエピ ポーラ調整の効果が上がることが推測された。

特に, 更新後の焦点距離は画像精度の向上に大きく 寄与していることより, 更新後の焦点距離の值を画面 距離と捉えると画面距離が探索区間内に存在するよう な民生用デジタルカメラの場合には工ピポーラ調整は 効率的に機能するものと推測された。

いっぽう，通常文化財の分野では $1 / 50$ あいは $1 /$ 20 程度の平面図が一般的であるがエピポーラ調整を考 慮した3DiVision は文化財計測の分野において十分有 効な手法であることが確認された。

以上の結果より, 本提案手法は地上基準点設置に伴 う測量および事前の内部標定要素の算出も必要とせず に測定対象物の三次元計測を行なうことが可能であ ク, デジタルカメラによる簡便的デジタル写真測量を 可能にするものと期待される。

(受付日2011.3.11, 受理日2011.5.13)

\section{参考文献}

江島裕司，大獄達哉，近津博文，2006. 民生用デジ夕 ルカメラの効率的カメラキャリブレーション手法に 関する研究, 写真測量とリモートセンシング, Vol. 45, No. 4 , pp. 54-57.

高橋洋二, 近津博文, 2010. 近接デジタル写真測量に
おける民生用デジタルカメラの精度評価，写真測量 とリモートセンシング, Vol. 49, No. 4, pp.260-268. 近津博文，他 3 名，2003。民生用デジタルカメラによ るデジタル写真測量システム“3DiVision”の構築, 写真測量とリモートセンシング, Vol. 42, No. 3, pp. $6-16$.

柳 秀治, 近津博文, 2009. 近接デジタル写真測量に おけるマクロレンズの有効性について，写真測量と リモートセンシング, Vol. 48, No. 6, pp.357-366.

Beyer H.A., 1991. An Introduction to Photogrammetric Camera Calibration, Invited paper, Seminaire Orasis, St. Malo, pp.37-42.

Faugeras O.D., Toscani G., 1987. Camera Calibration for 3D Computer Vision, Proc. Of International Workshop on Industrial Application of Machine Vision and Machine Intelligence, IEEE TH0166-9, pp.240-247.

Fraser C.S., 1996. Design Aspects of Utilizing Digital Photogrammetry for Deformation Measurements. Proceedings of the 8th FIG International Symposium on Deformation Measurements, pp. 115-123.

Fraser C.S., Hanley H.B., 2004. Developments in Close-Range Photogrammetry for 3D Modelling : the iWitness Example. International Archives of Photogrammetry, Remote Sensing and Spatial Information Sciences, Vol. XXXVI-5/W1, ISSN 1682-1777.

Habib A.F., Morgan M.F., 2003. Automatic calibration of low $^{-}$cost digital cameras. Optical Engineering, 42(4), pp.948-955.

Laebe, T., Foerstner W., 2004. Geometric Stability of Low-Cost Digital Consumer Cameras. International Archives of Photogrammety and Remote Sensing, 35(1), pp.528-535. 